\title{
Senate resignations mar academy's birthday
}

Alison Abbott

The European Academy of Sciences and Arts in Salzburg, Austria, celebrated its 15th anniversary last weekend with considerable pomp and ceremony. But the party has been pooped by allegations of mismanagement.

The accusations centre on a lack of transparency about the body's finances and the alleged failure of its president, Salzburg heart surgeon Felix Unger, to properly abide by the academy's rules.

Unger denies the allegations, which were first reported in the German newspaper Süddeutsche Zeitung on 4 March. He says that they have been made up by people who have tried, but failed, to get money from the academy.

The academy has some 1,200 members, nearly half of them from Austria or Germany. It is divided into seven sections, ranging in scope from religion to science, and has several institutes under its umbrella. These include

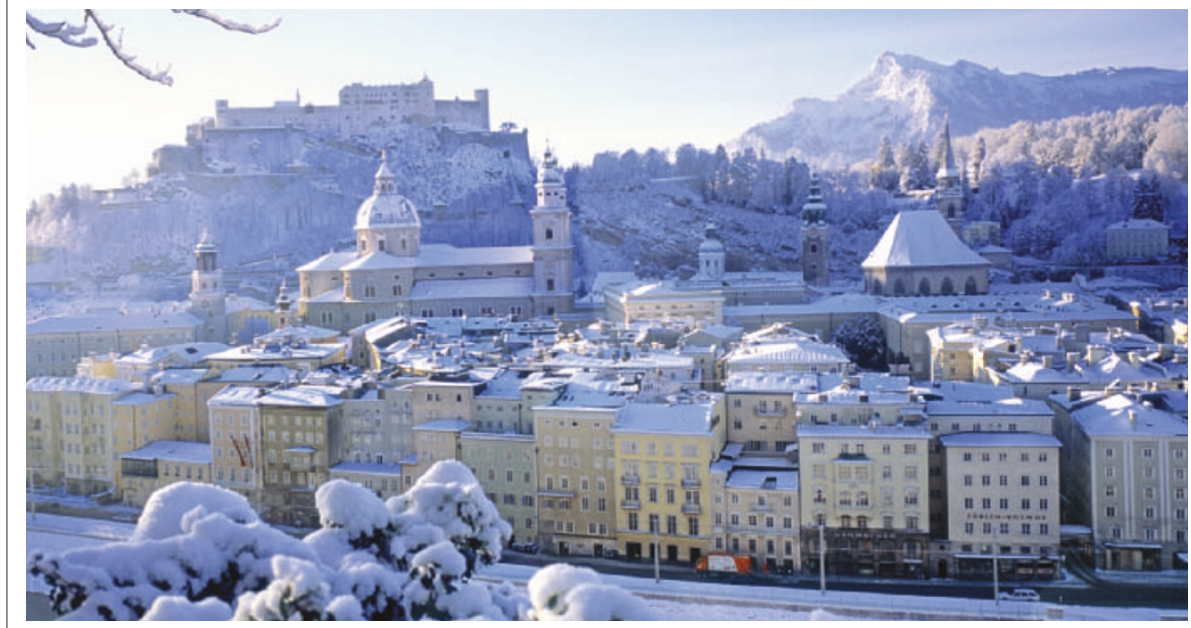

Cool location: Salzburg in Austria is home to the European Academy of Sciences and Arts. two run by Unger himself - the European Heart Institute and the European Institute of Medicine — which share the same address.

The academy has the patronage of the city of Vienna and the Austrian government, and has a grant of $€ 150,000$ (US\$200,000) from the European Commission, primarily to help cover its administrative costs. Its website also features a long list of companies and organizations designated as partners, benefactors, sponsors and donators.

But in the weeks running up to the anniversary celebration, three members of the academy's 18-strong senate resigned, expressing many concerns including lack of clarity on how money flows into, and out of, the academy.

Justin Stagl, a sociologist from the University of Salzburg and former chairman of the academy's nominations committee, said in his 8 February resignation letter that he

had resigned because he was unable to persuade Unger to stop nominating new members without discussion with, or the consent of, the senate. He also noted that many ordinary members had resigned and had criticized a 'personality cult', 'clientelism' and 'emptyboasting' at the academy.

Ernst Pöppel, a neuropsychologist at the University of Munich, was dean of the science section of the academy but says he resigned because Unger had become "a oneman show", changing the legal basis of the academy without discussion with the senate and not opening the accounts of the academy to scrutiny. "There is no transparency in the finances of the academy," he says. "For example, once a very large debt appeared, but was then wiped out, without anyone being able to find out why we had gone into debt and who had paid the debt off."

Bernd-Olaf Küppers, a philosopher from the University of Jena, who had been dean of the academy's humanities section, said that he too resigned on the grounds of its lack of financial transparency.

Unger says that the academy aspires to forge a European identity through interdisciplinary, transnational and bridge-building activities. He insists that the financial accounts have always been open to the senate. "It's all lies," he says.

Unger has his supporters in the senate. Eugen Biser, a theologian at the University of Munich and dean of the academy's world religion section, says that the accusations are born of "revenge and spite" and that the academy must allow the affair to blow over. Gilbert Fayl, foreign secretary at the academy, says the accusations are "purely personal". Additional reporting by Tamara Grüner

\section{Anthropologists walk tall after unearthing hominid}

Rex Dalton, San Diego

The remains of a hominid that date back nearly 4 million years have been uncovered by a field team in Ethiopia.

The discovery, announced in Addis Ababa on 4 March, looks set to provide crucial new evidence on early man's ability to walk upright.

Palaeoanthropologist Yohannes HaileSelassie and his colleagues found the bones near Mille Town, about 520 kilometres northeast of Addis Ababa. "It is too early to tell what species is represented," says Haile-Selassie, a curator at the Cleveland Museum of Natural History in Ohio.

A detailed description of the fossils will be submitted for publication once excavations and bone analysis are complete, which may not be for another year.

By studying the bones and muscle connections, anthropologists can decipher the mechanics of how different hominid species came to walk as they evolved from primates.

In addition to bones of the legs, hip and spine, the team uncovered a complete scapula, or shoulder bone. It is extremely rare to secure a scapula, as the thin bone is typically damaged by the forces of time.

The shoulder bone should provide important new data on arm and body functions. The leg bones indicate that the individual hominid was taller than Lucy (Australopithecus afarensis), a 3.2-millionyear-old fossil found in 1974 about $60 \mathrm{~km}$ south of the new site.
Examination of animal fossils found with the new hominid specimen suggests that it lived between 3.8 million and 4 million years ago.

The team's preliminary analysis indicates the hominid is a form of Australopithecus. It may be an Australopithecus anamensisknown only by a few bones and teeth found in Kenya, where that species lived about 4 million years ago.

The director of the Cleveland Museum, palaeoanthropologist Bruce Latimer, is a co-leader of the project, but he was not in the field when the fossils were found. Fossils on the surface were immediately collected by the team to prevent them from being damaged. Digging is expected to begin later this year as the team looks for other specimens. 